\title{
Review of Potential Microbial Effects on Flotation
}

\author{
Päivi Kinnunen ${ }^{1, *}$, Hanna Miettinen ${ }^{2}$ (D) and Malin Bomberg ${ }^{2}(\mathbb{D}$ \\ 1 VTT Technical Research Centre of Finland Ltd., Visiokatu 4, 33101 Tampere, Finland \\ 2 VTT Technical Research Centre of Finland Ltd., Tietotie 2, 02150 Espoo, Finland; \\ hanna.miettinen@vtt.fi (H.M.); malin.bomberg@vtt.fi (M.B.) \\ * Correspondence: paivi.kinnunen@vtt.fi
}

Received: 3 April 2020; Accepted: 10 June 2020; Published: 12 June 2020

\begin{abstract}
Microorganisms enter the flotation process mainly from intake water and ore material. The diversity and number of microorganisms can vary significantly from mine to mine. In flotation, the conditions including oxygen levels, temperature, and nutrients from ore, intake water, and reagents are often favorable for the microbial growth. The mining industry aims to close the water loops, which is expected to result in the accumulation of microorganisms in the process waters with potential effects on flotation performance. Bioflotation, bioleaching, and bio-oxidation have been studied for decades as tools for concentrating and dissolving minerals. In contrast, there is limited scientific literature or industrial knowledge about microorganisms that naturally inhabit and prevail in minerals processing applications over a wide $\mathrm{pH}$ range. Microorganisms affect minerals when they selectively attach to the surfaces, produce extracellular polymeric substances (EPS) and polysaccharides, oxidize or reduce the minerals, change the $\mathrm{pH}$ and Eh of the process solution, and degrade organic flotation chemicals. Microorganisms contain different structural components that affect their surface chemistry, charge, and behavior in flotation, but these properties may also change via adaptation and solution conditions. Almost all studies on flotation have focused on chemical and physical parameters, and the role of naturally occurring microorganisms has remained underexplored. Advances in genomics and proteomics offer possibilities to describe not only which microorganisms are present, but also which physiological functions are being exercised. This article reviews the current knowledge of microorganisms in various mineral processes, identifies potential microbe-mineral interactions in flotation, describes the gaps in current knowledge, and concludes with the potential effects of microorganisms on flotation, especially in closed water loops.
\end{abstract}

Keywords: flotation; bioflotation; microorganism; closed water loop; water recycling; mining industry

\section{Introduction}

Previously, bioflotation and bioflocculation using known selected microorganisms or produced biomolecules have been tested as flotation reagents, enhancing the selective separation of minerals at laboratory scale [1,2]. Microorganisms can flocculate finely dispersed minerals [3]. Bioleaching, which dissolves metals from sulphidic minerals in acidic conditions with the help of iron- and sulphur-oxidizing microorganisms [4-6], has been utilized commercially for decades [7]. In addition, biooxidation to pretreat gold-containing minerals with microorganisms has been used in the mining industry $[4,8]$. In contrast, there is limited scientific literature about microorganisms, which naturally inhabit and prevail in minerals processing applications over a wide range of $\mathrm{pH}$ levels (Figure 1). Scientific knowledge of the potential accumulation of microorganisms and their effects on closed water system in flotation is lacking [9], resulting in the clear need to study microbe-mineral interactions in more detail [10]. This article reviews the current knowledge of microorganisms in various mineral processes, identifies potential microbe-mineral interactions in flotation, describes the gaps in current 
knowledge and concludes with the potential effects of microorganisms on flotation, especially in closed water loops.

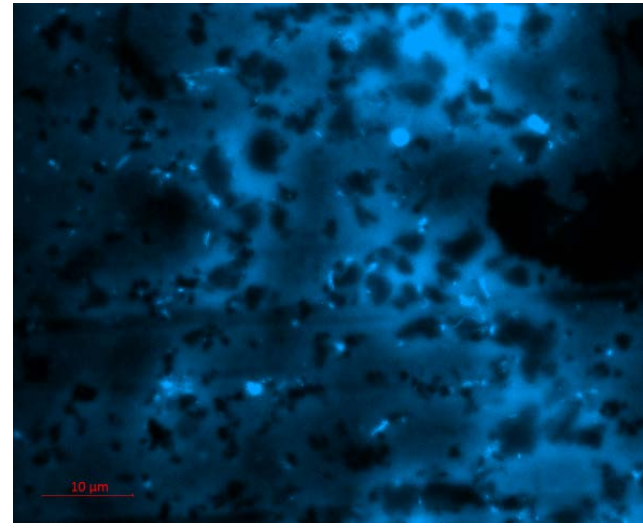

(a)

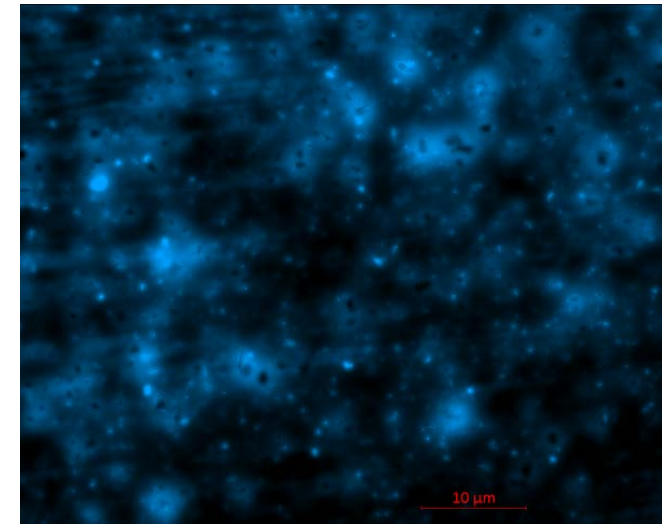

(b)

Figure 1. Epifluorescence image of DAPI (4',6-diamidino-2-phenylindole) stained Pb concentrate (a) and $\mathrm{Zn}$ rougher concentrate (b) samples showing the presence of microorganisms in flotation. Cells appear as bright blue spots and leftover stain as paler blue especially around black mineral particles. Scale bar is $10 \mu \mathrm{m}$.

\section{Flotation}

Flotation is the most common method for concentrating ore, and it is based on the separation of hydrophobic materials from hydrophilic ones [11] in an extremely complicated dynamic process including interactions of gas, liquid, and solid phases under flow. Much of the research has focused on electrostatic, van der Waals, hydrophobic, and capillary interactions, but there are also other forces that have remained uninvestigated, such as depletion interaction [12].

Recovery, grade, floatability, and selectivity of minerals determine flotation efficiency [13]. The performance of flotation is significantly affected by water quality and its fluctuations $[9,14]$. Many mines obtain raw intake water from several sources with varying qualities [13].

In the mine site, flotation is the highest water consuming unit process [11]. Therefore, the tendency to increase water circulation in the mine sites focuses especially on flotation and may result in the accumulation of microorganisms in the process. In addition to conventional physico-chemical flotation, bioflotation has been tested as a means for minerals separation. The scientific knowledge created in the bioflotation studies gives insights also to potential effects of naturally prevailing microorganisms in minerals processing.

\subsection{Closing the Water Loops in Flotation}

The mining industry aims to close the water loops in metals production processes due to environmental and economic aspects [15]. Mine sites in various geographic and climatic conditions may face water scarcity with too little water for running the operations or excess water resulting in discharges during rainfalls [16,17] or both over different seasons [18]. Water scarcity and water excess can have serious impacts on the business of the mining companies. Therefore, mine sites have increased water reuse from multiple sources [13] and many mining companies have set targets to reduce their water consumption [19].

The effects of water circulation on flotation performance depend on the mineral and reagents. Evdokimova et al. [20] reported that the circulation of water in an apatite flotation process significantly increased the consumption of flotation reagents. Already in traditional flotation without water recirculation, various complex surface interactions take place between dissolved reagents, colloidal species, solid-liquid-gas interfaces, and microorganisms. The complexity of these interactions further 
increases with closed water loops [9]. The temperature will also rise to the optimum level of many mesophilic organisms $\left(30-35^{\circ} \mathrm{C}\right)$ due to the short water circuits (water retention times in closed water loops are hours instead of days/months) presumably resulting in the increased growth of bacterial biomass. This will result in the accumulation of microorganisms in addition to various chemical elements, such as metals, thiosulphates, sulphates, and flotation chemicals, into the water. In the study of Liu et al. [21], a negative effect caused by the presence of microorganisms on metal recovery and flotation performance was shown. There is a clear need to understand the potential accumulation of microorganisms and the effects of this phenomenon on flotation efficiency $[9,21]$.

\subsection{Bioflotation and Flocculation}

Bioflotation and bioflocculation have been tested to enhance the selective separation of minerals [1,2]. In bioflotation, microorganisms or their products can be used as flotation collectors, depressants, and activators [22,23]. Bioflotation has been used only in laboratory scale so far [2,24] using mostly pure microbial cultures (Table 1) [25]. The quantity of microorganisms needs to be high for efficient bioflotation to compete with conventional flotation chemicals [22]. La Vars et al. [26] showed that mineral surface is modified already by low cell coverage.

The focus in previous research has been on bioflotation and flocculation of sulphide minerals, with very little effort on oxide minerals [1]. Bioflotation has been tested with various microorganisms for quartz [27], with Rhodococcus opacus in phosphate flotation [23], with Staphylococcus carnosus for fine coal tailings [28], with Bacillus pumilus, Alicyclobacillus ferrooxidans [29] and Ferroplasma acidiphilum for pyrite [30], and with Bacillus megaterium for selective flotation of sphalerite from a mineral mixture consisting of sphalerite and galena [31]. Merma et al. [32] showed that apatite-adapted Rhodococcus opacus cells increased the upper $\mathrm{pH}$ range for floatability of apatite from $\mathrm{pH} 7$ to $\mathrm{pH}$, and that these cells could be used as collector improving the separation of apatite from quartz, within a selective narrow window around $\mathrm{pH} 3$.

Table 1. A summary of bioflotation tests with pure microbial strains.

\begin{tabular}{|c|c|c|c|c|}
\hline Microorganism & Bioflotation & Tested pH Range & $\mathrm{T}\left({ }^{\circ} \mathrm{C}\right)$ & Ref. \\
\hline $\begin{array}{l}\text { Leptospirillum } \\
\text { ferrooxidans }\end{array}$ & $\begin{array}{l}\text { Flocculation of chalcopyrite and pyrite. } \\
\text { Greater depression of chalcopyrite compared } \\
\text { to pyrite. }\end{array}$ & $1.8-11$ & 30 & {$[33,34]$} \\
\hline $\begin{array}{l}\text { Acidithiobacillus } \\
\text { ferrooxidans }\end{array}$ & $\begin{array}{l}\text { Oxidation of pyrite surface and depressive } \\
\text { effect on pyrite. }\end{array}$ & 1.8 & 30 & [26] \\
\hline Rhodococcus opacus & $\begin{array}{l}\text { Use as biocollector and biofrother. Improved } \\
\text { separation of apatite from quartz in } \\
\text { phosphate flotation. }\end{array}$ & $2-12$ & $20-28$ & {$[23,32]$} \\
\hline $\begin{array}{l}\text { Staphylococcus } \\
\text { carnosus }\end{array}$ & Biocollector in fine coal tailings flotation. & $7-10$ & room temp. & [28] \\
\hline Bacillus pumilus & $\begin{array}{l}\text { Change of surface chemical properties of } \\
\text { pyrite, oxidation of iron and sulphur for the } \\
\text { use of depressant in pyrite flotation. }\end{array}$ & $3-6$ & 30 & [29] \\
\hline $\begin{array}{l}\text { Alicyclobacillus } \\
\text { ferrooxidans }\end{array}$ & $\begin{array}{l}\text { Change of surface chemical properties of } \\
\text { pyrite, oxidation of iron and sulphur for the } \\
\text { use of depressant in pyrite flotation. }\end{array}$ & $3-5$ & 30 & [29] \\
\hline $\begin{array}{l}\text { Ferroplasma } \\
\text { acidiphilum }\end{array}$ & Good depressant for pyrite. & $2.5-10$ & 37 & [30] \\
\hline Bacillus megaterium & $\begin{array}{l}\text { Selective flotation of sphalerite from } \\
\text { sphalerite-galena. }\end{array}$ & $2-10$ & $\begin{array}{l}\text { room temp. } \\
\quad \text { or } 37\end{array}$ & [31] \\
\hline
\end{tabular}

Halophilic microorganisms may be a solution for more environmentally friendly bioflotation processes in areas where seawater is abundant, and freshwater is scarce [35]. Halophiles have been shown to produce many different kinds of metabolites, such as polyhydroxyalkanoates (PHA), ectoines, and bio-surfactants in addition to salt tolerant enzymes [36]. The adsorption of halophilic bacteria, especially Halobacillus sp., specifically to pyrite, occurred within 5-10 min of exposure, but this required that the bacteria produce hydrophobic moieties on their cell wall and thus act as 
pyrite bio-depressants [35]. Nevertheless, specific bio-depressant microorganisms could in the future substitute lime as a depressing agent [35].

When bioflotation microorganisms are adapted to minerals, the bioflotation performance may improve. In adaptation, the cells respond to stimuli in their environments, which makes the cells more tolerable. For example, adaptation of Bacillus megaterium to the target minerals resulted in better bioflotation performance compared to the unadapted strains [31]. It is important to note that microorganisms can also decrease the flotation process performance. In the study of Liu et al. [37], Escherichia coli cells had a negative effect on the flotation efficiency of chalcopyrite, pyrite, and gold in a porphyry ore. Microbial cultures may thus have positive, neutral, or negative impacts on flotation.

Not only microorganisms, but also their metabolites and secreted compounds can have an effect on flotation. Bioflocculants are biopolymers, which form bridges and rely on the agglomeration of fine particles [38]. Bioflocculants have been analyzed to contain hydroxyl-, carboxyl-, and amino-groups, and polysaccharides and proteins [38,39]. The polymeric bioflocculant QZ-2 produced by Bacillus salmalaya strain 139SI was shown to remove $\mathrm{As}^{3+}, \mathrm{Zn}^{2+}, \mathrm{Cu}^{2+}, \mathrm{Cd}^{2+}$, and $\mathrm{Pb}^{2+}$ from industrial waste water and the best results were obtained at neutral to alkaline $\mathrm{pH}$ [39]. A biosurfactant produced by Rhodococcus erythropolis was used as a flotation chemical for hematite and quartz [40].

\section{Microbe-Mineral Interactions in Flotation}

Microorganisms affect minerals by attaching to the surfaces, oxidizing, or reducing the mineral, and producing EPS and polysaccharides [1]. In addition, the microbial activity can crucially change the $\mathrm{pH}$ (from 9.5 to 3) and $\mathrm{Eh}$ (from $+400 \mathrm{mV}$ to $-200 \mathrm{mV}$ ) in a short time [9] and affect the chemicals needed in flotation. Various microbe-mineral interactions are described in the following sections.

\subsection{Cell Structure}

Microorganisms' cell walls contain different components that affect their surface chemistry, charge, and behavior in flotation. The bacterial cell membranes vary in protein and polysaccharide compositions from strain to strain and thus show different biochemical properties [2] and different surface charges [41]. The negative charge of the microbial surface is primarily due to the presence of peptidoglycan [42]. The lipids in the cell membranes of archaea and bacteria are different [43]. While bacteria have ester linkages bonding fatty acids and glycerol, the archaeal lipids have ether linkages bonding glycerol and hydrophobic side chains with no fatty acids [30]. The lipids in the cell wall cause hydrophobic behavior. Hydrophobicity results in flocculation of cells and adhesion to solids and to air bubbles. If the microbial surface charge is increased, the possibilities for polar interactions with water molecules are increased with simultaneous decrease in hydrophobicity [42].

The ionization of surface groups leads to charged cell surfaces depending on the $\mathrm{pH}$ [42]. The $\mathrm{pH}$ value also affects the surface charge of minerals. If the cells and minerals have the same surface charge, repulsive forces will hinder adsorption. When the $\mathrm{pH}$ is close to the bacterial isoelectric point (IEP), repulsion does not exist. When the $\mathrm{pH}$ is far from the bacterial IEP, the cell surfaces are charged, and the electrostatic repulsive forces take place depending on the mineral surface charge [27]. Microbial cells are negatively charged in solutions with $\mathrm{pH}$ above the microbial IEP and positively charged, when the solution $\mathrm{pH}$ is below the microbial IEP. Under physiological conditions, the surfaces of microorganisms are mostly negatively charged, because the functional groups on the microbial cell surfaces are negatively charged. The substrate for microbial growth as well as the growth phase affect the microbial surface charge [41] and subsequently the bioflotation efficiency [24]. Hydrophobic growth substrates have been shown to support more hydrophobic cells, which as a consequence attach to the hydrophobic substrates instead of charged particles [44,45]. Moreover, the surface properties of mineral-adapted bacterial cells can be clearly different from those of unadapted cells [46]. For example, pyrite and chalcopyrite adapted cells of Paenibacillus polymyxa produced more proteins on the cell surface than cells unadapted to these minerals [47]. The presence of minerals modifies the cell wall functional groups or metabolic products and affects the cell zeta-potential and hydrophobicity [32]. 


\subsection{Attachment of Microorganisms on Mineral Surface}

There are different steps in bacterial attachment to surfaces starting from the transport of microorganisms to the surface, initial adhesion, firm attachment of microorganisms, and surface colonization [48]. The bacterial adhesion is based on the electrical potential and hydrophobicity [41] being strongest, when the zeta-potential measurements show the biggest difference between cells and mineral [24]. The initial reversible bacterial adhesion to mineral surface requires that the cells are in close vicinity of the mineral surface [1]. In the tests, it has been shown that the microorganisms adhere to the mineral surfaces within minutes [23,49] and have an effect on the floatability of the minerals [23]. This is followed by the irreversible adhesion via molecular mediated binding and microbially produced extracellular polymeric substances (EPS) [1] formed of polysaccharides, proteins, nucleic acids, and lipids [2]. Alternatively, shear stress can cause the detachment of microorganisms from the mineral surface [24].

Govender and Gericke [25] used EPS extracted from bioleaching cultures to improve the bioflotation of chalcopyrite. Selective flotation of sphalerite from a mineral mixture consisting of sphalerite and galena was possible with extracellular secretions of Bacillus megaterium [31]. Extracellular proteins isolated from Paenibacillus polymyxa were used in selective mineral separation of pyrite, chalcopyrite, quartz, sphalerite, and galena [50]. The fractioned proteins rendered pyrite and chalcopyrite particles hydrophilic and galena, sphalerite and quartz showed enhanced surface hydrophobicity. This enabled the selective separation of sphalerite, galena and quartz from pyrite and chalcopyrite after prior treatment with bacterial proteins. In the study of La Vars et al. [26], EPS was detected within $2 \mathrm{~h}$ of contact with Acidithiobacillus ferrooxidans on pyrite surface rendering the surface hydrophilic. Acidithiobacillus ferrooxidans produced polysaccharides and fatty acid compounds in the initial adhesion stage, and only later hydrophobic protein-and nucleic acid-rich EPS. This observation means that the excreted compounds can change over time depending on the stage of EPS formation [26].

Mixed cultures have resulted in increased EPS production and increased attachment on mineral surfaces compared to pure cultures [51]. Therefore, naturally occurring mixed cultures in the process water may have very different effects on flotation compared to the studies done in the laboratory environment with pure microbial cultures. When biofilm is formed on the surface of the mineral, surface charge, composition, and hydrophobicity can change [2]. Some of the microbe-mineral interactions occur within the EPS layer. For example, bioleaching has been considered as a result of interfacial processes taking place in EPS [52-54]. The micro-environment within EPS may differ from the actual conditions in the solution and protect the microorganisms against changes in $\mathrm{pH}$, redox, and chemicals [52].

Microorganisms have been shown to attach selectively to various mineral surfaces [23,55], resulting in uneven distribution of EPS on the particle surface. Selective attachment on sulphidic minerals of the ore has been observed for Metallosphaera hakonensis [56] and for bioleaching microorganisms [2]. The bioleaching microorganism Leptospirillum ferrooxidans was preferentially attached to pyrite over chalcopyrite resulting in biofilm formation on pyrite surface, but not on chalcopyrite surface [34]. Leptospirillum ferrooxidans was shown to have a higher affinity to chalcopyrite than to pyrite, which resulted in higher depression of chalcopyrite in flotation and better settling behavior [26]. In contrast, Paenibacillus polymyxa enforced a higher depression of pyrite than chalcopyrite, which resulted from a higher proportion of polysaccharides produced on the cell surface in pyrite adapted cells compared to chalcopyrite adapted cells, which also rendered the pyrite-adapted cells less hydrophobic [47]. Bacillus pumilus and Alicyclobacillus ferrooxydans strains have been shown to produce biosurfactants that change the chemical properties of pyrite surfaces, which increased the frothability of pyrite [29].

The adaptation of cells to the specific minerals affects the amount of extracellular proteins produced and subsequently the flotation performance [31]. With the thermophile Metallosphaera hakonensis, the surface coverage of biofilm was most extensive close to the optimal temperature for growth of the 
microorganisms [56]. As a consequence, the adaptation time and whether the operational environment is close to the optimal conditions of the microorganism, can also be important factors in the attachment.

\subsection{Sulphur- and Iron-Oxidizing or Reducing Microorganisms}

When water is recirculated in the processes, the substances, such as metal ions and soluble sulphur species, in the water are also recirculated [13]. Sulphate-reducing bacteria can produce reduced sulphur compounds, which can help as reductants in flotation [10]. Iron- and sulphur-oxidizing microorganisms oxidize sulphidic minerals and dissolve various anions and cations to the solution. Typically, iron and sulphur oxidation in bioleaching take place at the $\mathrm{pH}$ below 3 [57], but bioleaching can also occur in an alkaline $\mathrm{pH}$ [58]. The $\mathrm{pH}$ in the flotation process varies case-by-case from acidic to alkaline. Sulphur- and iron-oxidizing microorganisms may function as depressants of pyrite but not of chalcopyrite or molybdenite in flotation using water with salinities ranging from fresh to saline $\left(\mathrm{NaCl} 35 \mathrm{~g} \mathrm{~L}^{-1}\right)$ at neutral $\mathrm{pH}$ [59]. The adhesion of Leptospirillum ferrooxidans cells on chalcopyrite and pyrite caused flocculation of both minerals [33]. Acidithiobacillus ferrooxidans had a depressive effect on pyrite [26] and Leptospirillum ferrooxidans on chalcopyrite [34].

Acidithiobacillus ferrooxidans has been shown to accelerate the oxidation of the pyrite surface to sulphur compounds and thereby affect the flotation performance [26] and to selectively depress pyrite in coal flotation; thus, by removing pyritic sulphur from coal, it could be used as a potential depressing agent replacing sodium cyanide [60]. Biological oxidation of metal sulphides proceeds via various intermediates, such as thiosulphate, tetrathionate, other polythionates, sulphate, elemental sulphur, $\mathrm{H}_{2} \mathrm{~S}$, and $\mathrm{H}_{2} \mathrm{~S}_{2}[54,61,62]$. Produced sulphate ions in the presence of high calcium ion concentrations can cause scaling and precipitation of e.g., gypsum. Gypsum precipitates also affect the interactions between flotation reagents and minerals [63]. In the study of Kirjavainen et al. [64], thiosulphate ions reduced the effect of hydrophilic compounds on sulphide particles resulting in improved flotation.

\subsection{Interactions with Flotation Reagents}

Flotation reagents are organic chemicals, which microorganisms may use as substrates and thereby decrease the available reagents for flotation. On the other hand, flotation chemicals may also inhibit the growth and activity of microorganisms. This has been a concern with flotation concentrates, especially in bioleaching applications, which still contained some reagents. Sulphide mineral collectors have been shown to be mostly biodegradable. Chen et al. [65] used activated sludge from a water treatment plant to test the degradability of different collectors. Sodium diethyldithiocarbamate, ammonium butyl-dithiophosphate, and n-butyl xanthate were readily biodegradable at the concentration of $30 \mathrm{mg} \mathrm{L}^{-1}$, whereas ethylthionocarbamate was less easily biodegraded. The microbial consortium enriched from the activated sludge of the wastewater treatment plant also easily degraded xanthates and dithiophosphate in the study of Cheng et al. [66]. Collectors, sodium isopropylxanthate (SIPX), dodecylammonium acetate, and sodium oleate, were biodegraded by Paenibacillus polymyxa [67]. Flotation reagents including various collectors and frothers were shown to have either positive or negative effect on the activity of Leptospirillum ferrooxidans depending on the chemical composition and concentration [7]. Dehghan and Dianati [68] used similar flotation reagents and concentrations as have been used in industrial lead-zinc flotation, which resulted in positive effects on the growth and on increased bioleaching of zinc with Acidithiobacillus ferrooxidans, Acidithiobacillus thiooxidans, and Leptospirillum ferrooxidans.

In addition to biodegradation potential of flotation reagents and positive impact on microbial growth, the reagents may also have adverse effects on microorganisms. Dopson et al. [69] observed that relevant concentrations of collectors and frothers can decrease the bioleaching of chalcopyrite due to the toxicity of these compounds to Sulfolobus metallicus. In contrast, potassium amyl xanthate (PAX) increased the bioleaching rate, which was expected to occur due to the solubilization of the passivating sulphur layer covering the mineral surface. Okibe and Johnson [70] showed a wide variety of relative toxicity and sensitivity to flotation reagents by microorganisms. Dithiophosphates and 
mercaptobenzothiol were the most toxic flotation reagents to the tested microorganisms. Leptospirillum was the most sensitive to many of the reagents [70]. Jafari et al. [71] studied the effects of flotation chemicals in low concentrations on the activity and growth of iron oxidizing acidophiles (Acidithiobacillus ferrooxidans and Leptospirillum ferrooxidans). In their study, no considerable effects were detected. However, soil microorganisms have shown clear inhibition with sodium isobutyl xanthate (SIBX) and sodium isopropyl xanthate (SIPX) in the concentrations of 5-300 $\mathrm{g} \mathrm{ton}^{-1}$ soil [72] and with butyl xanthate, butyl dithiosphosphate, and sodium diethyldithiocarbamate in the concentration of $100 \mathrm{~g} \mathrm{ton}^{-1}$ soil [73]. Adaptation of microorganisms is also possible. For example, the adaptation of Paenibacillus polymyxa and Pseudomonas putida strains to xanthate has been demonstrated [74].

\section{Microbiology in Flotation}

There is a pronounced lack of knowledge on how naturally occurring microorganisms affect flotation performance [37]. In addition, the effect of microbial numbers is not straight forward. For example, when the Rhodococcus erythropolis concentration was increased, the hematite floatability was increased until a certain point, where after the floatability started to decrease again [49]. Microorganisms enter the flotation process from intake water, ore material and recycled water. Nutritional inputs have especially effects on the microbial consortia in low nutrient environments [75].

\subsection{Microorganisms from Water and Ore Material}

Intake water to flotation can be recovered from lakes, rivers, and the sea. In addition, treated effluent including bacteria has been used as water source in some mines [21]. The typical bacterial numbers in lake and river waters is at the levels of $10^{6}$ to $10^{7}$ cells $\mathrm{mL}^{-1}$ [76]. Different lakes have different bacterial communities, which also vary within lakes along environmental gradients [77]. Yannarell and Triplett [78] studied the bacterial communities of 30 lakes in Wisconsin and showed a profound difference between northern and southern lakes, with higher bacterial numbers in the southern lakes. Various bacteria and archaea have been found also in natural rock leaching environments [5]. Acidic mine waters were shown to contain high diversity and microbial numbers reaching $10^{6}-10^{7} 16 \mathrm{~S}$ rRNA gene copies $\mathrm{mL}^{-1}$ [79]. The bacterial counts in different parts of a sulphide flotation circuit have been in the range of $10^{5} \mathrm{CFU} \mathrm{mL} \mathrm{m}^{-1}$ in process water to up to $10^{9} \mathrm{CFU} \mathrm{mL}^{-1}$ in concentrate pulp [9]. In an apatite flotation process, the bacterial counts ranged from $10^{6}$ to $10^{7}$ cells $\mathrm{mL}^{-1}$ being highest during summer months of June to August [20]. The dominating bacteria in the circulating water of the apatite flotation process were identified as Acinetobacter, Pseudomonas, and Stenotrophomonas. The Cerro Verde mine uses river water consisting partly of untreated wastewater and high bacterial content of up to $10^{8} \mathrm{CFU} \mathrm{mL} \mathrm{mL}^{-1}$ has created challenges in flotation [37]. The diversity and number of microorganisms in the intake water can vary significantly from mine to mine, and present complications in the process performance.

Microorganisms are present naturally and even also in large numbers in the ores [22]. For example, indigenous microorganisms with Proteobacteria as the dominant taxa were identified in natural monazite ore [75]. Uranium ores retrieved from Indian underground mines were likewise dominated by Gammaproteobacteria but contained also relatively high proportions of Acidobacteria and Bacteroidetes, especially in organic carbon rich rock [80,81]. Bacterial isolates grown from freshly exposed organic carbon rich black shale (Kupfershiffer) from the Lubin mine (Poland) were shown to belong to Gammaproteobacteria, Firmicutes, and Actinobacteria [82]. These bacterial strains were shown to retrieve organic carbon directly from the bituminous black shale. Isolated bacterial strains from low-grade iron ores, classified as conglomerates and shale, from the Sishen mine in South Africa, were shown to belong to Proteobacteria, Firmicutes, Bacteroidetes, and Actinobacteria [83]. The diversity of microorganisms inhabiting ores is likely much higher, because the majority of microorganisms in nature are not culturable on the media used in these studies. In addition, the studies above generally used rich media, such as R2A, Nutrient Agar, and Luria-Bretani agar as growth medium, which effectively 
excludes microorganisms susceptible to high organic carbon concentrations, or microbes requiring more defined growth conditions.

\subsection{Flotation Conditions for Microbial Growth}

In flotation, the conditions including oxygen levels, temperature, and nutrients from reagents are often favorable for the bacterial growth [21]. Organic carbon levels have been shown to rise in some parts up to $>200 \mathrm{mg} \mathrm{L}^{-1}$ [9]. Solution conditions, such as $\mathrm{pH}$ and ionic strength, and the surface properties, such as hydrophobicity and zeta-potential, affect the attachment of microorganisms on mineral surfaces [27]. When the $\mathrm{pH}$ is close to the IEP value of the bioreagent solution, there is no charge at the bioreagent surface, which makes the floc formation possible [23]. The level of $\mathrm{pH}$ has an effect on availability of various ions and metals, and thereby supports either inhibitory or growth enhancing effects or both. Ghashoghchi et al. [84] investigated Bacillus licheniformis cells and metabolites in bioflocculation of kaolin and quartz. Typically, elevation of the $\mathrm{pH}$ value resulted in the decrease in the reagent adsorption and bio-flocculation [84]. When water is circulated in the flotation circuit, the concentration of various elements starts to increase. The increase in the ionic strength of the solution results in the increased capability of microbial adhesion to negatively charged surfaces and the ability of bacteria to form aggregates, since the ions can act as bridges between the cell and mineral surfaces [42].

Explosives used at mine sites contain large amounts of nitrogen compounds, which support the growth of microorganisms. The share of nitrogen ending up in the mine sites drainage water varies greatly, ranging from 0.2 to $28 \%$ of the used explosive mass and consisting mostly of nitrate and ammonia and to lesser extend of nitrite [85]. The amount of nitrogen ending up to different raw ore grades ranged from $6.5 \mathrm{mg} \mathrm{N}_{\text {tot }} \mathrm{kg}^{-1}$ ore to $34.7 \mathrm{mg} \mathrm{N}_{\text {tot }} \mathrm{kg}^{-1}$ ore in a Swedish (LKAB Kiruna) mine using emulsified explosive [86]. From this nitrogen, about $43 \%$ was found from the tailings and the rest mainly from the process water.

Flotation is dependent on temperature [87], which affects the flotation kinetics [88]. The increase in the pulp temperature may improve the minerals recoveries [88]. Water recycling is likely to increase the temperature of the pulp, which is also expected to support the growth and activity of the microorganisms.

\subsection{Management of Microorganisms}

In flotation experiments with apatite and calcite minerals with, and without, bacteria enriched from the flotation process, all the tested bacterial suspensions from $10^{2}$ to $10^{7}$ cells $\mathrm{mL}^{-1} \mathrm{had}_{\mathrm{a}}$ negative effect on the flotation performance [20]. Of the tested biocides (hydrogen dioxide, sodium hypochlorite, and potassium permanganate) the most efficient was sodium hypochlorite at 2 to $5 \mathrm{mg}$ $\mathrm{L}^{-1}$ concentrations, which almost completely killed the bacterial suspension in $5 \mathrm{~min}$. This treatment cut the consumption of the collector mixture.

The effect of disrupted cells on flotation was studied by Liu et al. [89]. The disrupted cells had a more negative effect on the copper flotation compared to the intact cells of $E$. coli. Microbial cells can be disrupted in grinding mills and flotation circuits due to mechanical and chemical forces. The intact cells eventually adsorb more selectively to the mineral surfaces compared to lysed cells. The possible effects of cell disruption need to be taken into account in the management of microbes, since the disinfection of water with bactericides may only kill the microorganisms, but it does not necessarily remove the effects on flotation [89]. In this respect, only killing the microorganisms may not be enough in the management of microorganisms in flotation, but the physical removal of the dead and living cells by e.g., filtration, may be necessary.

\section{Identified Gaps and Future Directions}

Closed water loops have gained interest in physico-chemical flotation research and can also give insights into future microbial aspects. Typically, water recycling has resulted in negative effects in 
flotation performance [90]. A change in ionic strength of the plant water as a result of water circulation has negatively affected the behaviour of xanthate [91]. $\mathrm{Ca}^{2+}$ and $\mathrm{SO}_{4}{ }^{2-}$ ions [92], reduced sulphur compounds such as $\mathrm{SO}_{3}{ }^{2-}, \mathrm{S}_{2} \mathrm{O}_{3}{ }^{2-}, \mathrm{S}_{2} \mathrm{O}_{5}{ }^{2-}$, and $\mathrm{S}_{4} \mathrm{O}_{6}{ }^{2-}$, cations of ferrous and non-ferrous metals, residual chemical reagents and their degradation products [93] are typical in the recycled waters. Sulphate has been shown to result in a negative effect on flotation [94]. Thiosulphate ions contribute to altering mineral surface properties and consume dissolved oxygen [95]. Accumulating bicarbonate ions depress the metal containing minerals and increase the recovery of minerals from the gangue and can also overconsume reagents through oxidation [96]. Various precipitates including gypsum, silica, iron hydroxide, and magnesium carbonate can cause mineral surface contamination in recycled streams [14].

Several important physico-chemical and microbiological parameters were identified affecting flotation process (Table 2).

Table 2. Parameters affecting flotation process.

\begin{tabular}{|c|c|c|}
\hline Parameter & Effect & References \\
\hline Sulphur and iron & $\begin{array}{l}\text { Iron- and sulphur-oxidizing microorganisms oxidize sulphidic } \\
\text { minerals and dissolve various anions and cations to the solution. }\end{array}$ & {$[54,61,62]$} \\
\hline Flotation reagents & $\begin{array}{l}\text { Microorganisms may use flotation reagents as substrates and } \\
\text { decrease the available reagents for flotation. Flotation chemicals } \\
\text { may also inhibit the growth and activity of microorganisms. }\end{array}$ & {$[7,68-71]$} \\
\hline $\mathrm{pH}$ & $\begin{array}{l}\text { Microbial activity can crucially change the } \mathrm{pH} \text { in a short time. } \\
\text { The } \mathrm{pH} \text { value affects the surface charge of minerals. }\end{array}$ & {$[9,27]$} \\
\hline Redox & Microbial activity can crucially change the Eh in a short time. & [9] \\
\hline Temperature & $\begin{array}{l}\text { The flotation temperature is often favorable for the } \\
\text { bacterial growth. }\end{array}$ & {$[21]$} \\
\hline Nutrients & $\begin{array}{l}\text { Explosives contain nitrogen compounds, which can support the } \\
\text { growth of microorganisms. }\end{array}$ & {$[85,86]$} \\
\hline Population density & $\begin{array}{l}\text { Quantity of microorganisms affects bioflotation efficiency. The } \\
\text { effect of microbial numbers is not straight forward. }\end{array}$ & {$[22,49]$} \\
\hline Microbial diversity & $\begin{array}{l}\text { Bacterial cells vary from strain to strain and show different } \\
\text { biochemical properties and different surface charges. Mixed } \\
\text { cultures have resulted in increased EPS production and } \\
\text { attachment on mineral surfaces compared to pure cultures. }\end{array}$ & {$[2,41,51]$} \\
\hline Adaptation & $\begin{array}{l}\text { Adaptation of cells to the specific minerals affects the amount of } \\
\text { extracellular proteins produced and flotation performance. }\end{array}$ & {$[31,46]$} \\
\hline Growth phase & Growth phase affects surface chemistry of microorganisms. & [24] \\
\hline Dead/alive cells & $\begin{array}{l}\text { Disrupted cells can have a negative effect on flotation. Physical } \\
\text { removal may be necessary. }\end{array}$ & {$[89]$} \\
\hline Mineral type & $\begin{array}{l}\text { Selective microbial attachment on various mineral surfaces and } \\
\text { uneven distribution of EPS on the particle surface. } \\
\text { Microorganisms are present in large numbers in the ores. }\end{array}$ & {$[2,22,23,56]$} \\
\hline Intake water & $\begin{array}{l}\text { Different natural waters have different bacterial amounts and } \\
\text { communities. Treated effluents have been used in some mines. }\end{array}$ & {$[21,76,77]$} \\
\hline
\end{tabular}

Previously, bioflotation enhancing the selective separation of minerals has been studied in laboratory scale. Bioleaching to dissolve metals and bio-oxidation to pretreat gold-containing minerals have been utilized commercially for decades. In contrast, there is limited scientific literature about microorganisms that naturally prevail and dominate in minerals processing applications in a wide range of $\mathrm{pH}$ levels.

Various microorganisms enter the flotation process from the ore, intake water, and recycled water. Minerals of the ore, flotation chemicals, nitrogen from explosives, and suitable temperature can support the growth of these microorganisms. The microorganisms can have a significant effect on flotation efficiency, even though this phenomenon is poorly understood [21].

Since there are clear gaps in the current knowledge on naturally occurring microorganisms on flotation, there is a need to investigate this phenomenon more. In addition, the information of microorganisms needs to be combined with water quality data of the mine [37]. Almost all studies on flotation have focused solely on chemical and physical parameters. For example, suspended solids levels have shown a negative impact on flotation [14]. When the solids are removed, also a significant 
amount of microorganisms attached on the surface of particles are removed. We need to identify and better understand what the effects of solids, and the effect of microorganisms attached to the solids, are. Therefore, microbiological surveys are needed together with chemical and physical surveys at the mine sites. Many existing and commercial microbial detection techniques may not be applicable in the harsh mining environments, and also microbial detection methods need improvement for easier analytics.

Often, single strains of bacteria have been used in the experiments with synthetic water, although the real water-microbe systems are more complex [21]. The studies on bioflotation and bioflocculation have generally not been done using actual ore samples and microorganisms from ore deposits [1]. As a result, the observations done in the laboratory environments are not necessarily representative and can vary significantly from the ones in the real plant operations. We clearly need real data from actual mining and flotation environments to understand the effect of naturally occurring microorganisms on flotation. In addition, advances in genomics and proteomics, offer possibilities to describe not only which microorganisms are present, but also what physiological functions are being exercised. This potential provided by molecular biology methods should be exploited in addition to monitoring microbial behavior, also to optimize conditions for more appropriate flotation.

\section{Conclusions}

Microbial cultures may have positive, neutral, or negative impacts on flotation. Already in conventional flotation, various complex interactions take place between dissolved reagents, colloidal species, solid-liquid-gas interfaces, and microorganisms. Closing the water loop is expected to further accumulate the microbes in flotation and to increase the complexity of the interactions. Flotation conditions can support the growth of various microorganisms. Naturally occurring mixed cultures in the process water may have very different effects on flotation compared to the studies done in laboratory environment with microbial pure cultures. Microbiological surveys are needed together with chemical surveys at the actual mine sites. The knowledge about the amounts and diversity of microorganisms in addition to chemical analytics and process performance data is necessary to understand the effects of microorganisms on the flotation performance. To be able to manage the flotation process optimally interdisciplinary approaches, including metagenomic and metaproteomic methods combined with mineral and chemical expertise, are needed in the future.

Author Contributions: Conceptualization, P.K.; writing-original draft preparation, and review and editing, P.K., H.M., and M.B. All authors have read and agreed to the published version of the manuscript.

Funding: This project has received funding from the European Union's Horizon 2020 Research and Innovation program under Grant Agreement no. 730480, ITERAMS project (Integrated mineral technologies for more sustainable raw material supply).

Acknowledgments: We thank Kirsten Corin for language editing.

Conflicts of Interest: The authors declare no conflict of interest. The funders had no role in the design of the study; in the collection, analyses, or interpretation of data; in the writing of the manuscript; nor in the decision to publish the results.

\section{References}

1. Dwyer, R.; Bruckard, W.J.; Rea, S.; Holmes, R.J. Bioflotation and bioflocculation review: Microorganisms relevant for mineral beneficiation. Miner. Proc. Ext. Met. 2012, 121, 65-71. [CrossRef]

2. Behera, S.K.; Mulaba-Bafubiandi, A.F. Microbes assisted mineral flotation a future prospective for mineral processing industries: A review. Miner. Proc. Ext. Met. 2017, 38, 96-105. [CrossRef]

3. Seifelnassr, A.A.S.; Abouzeid, A.-Z.M. Exploitation of bacterial activities in mineral industry and environmental preservation: An overview. J. Miner. 2013. [CrossRef]

4. Brierley, C.L. How will biomining be applied in future? T. Nonferr. Metal. Soc. 2008, 18, 1302-1310. [CrossRef]

5. Pradhan, N.; Nathsarma, K.C.; Srinivasa Rao, K.; Sukla, L.B.; Mishra, B.K. Heap bioleaching of chalcopyrite: A review. Miner. Eng. 2008, 21, 355-365. [CrossRef] 
6. Johnson, D.B. Biomining—Biotechnologies for extracting and recovering metals from ores and waste materials. Curr. Opin. Biotech. 2014, 30, 24-31. [CrossRef] [PubMed]

7. Jafari, M.; Shafaei, S.Z.; Abdollahi, H.; Gharabaghi, M.; Chehreh Chelgani, S. Effect of flotation reagents on the activity of L. Ferrooxidans. Min. Proc. Ext. Met. 2018, 39, 34-43. [CrossRef]

8. Clark, M.E.; Batty, J.D.; van Buuren, C.B.; Dew, D.W.; Eamon, M.A. Biotechnology in minerals processing: Technological breakthroughs creating value. Hydrometallurgy 2006, 83, 3-9. [CrossRef]

9. Levay, G.; Smart, R.S.C.; Skinner, W.M. The impact of water quality on flotation performance. J. S. Afr. I. Min. Metall. 2001, 101, 69-76.

10. Rao, K.H.; Vilinska, A.; Chernyshova, I.V. Minerals bioprocessing: R \& D needs in mineral biobeneficiation. Hydrometallugry 2010, 104, 465-470.

11. Gunson, A.J.; Klein, B.; Veiga, M.; Dunbar, S. Reducing mine water requirements. J. Clean. Prod. 2012, 21, 71-82. [CrossRef]

12. Choi, J.; Kim, G.; Choi, S.; Kim, K.; Han, Y.; Bradford, S.A.; Choi, S.Q.; Kim, H. Application of depletion attraction in mineral flotation: I. Theory. Minerals 2018, 8, 451. [CrossRef]

13. Liu, W.; Moran, C.J.; Vink, S. A review of the effect of water quality on flotation. Miner. Eng. 2013, 53, 91-100. [CrossRef]

14. Muzenda, E. An investigation into the effect of water quality on flotation performance. World Acad. Sci. Eng. Technol. 2010, 45, 237-241.

15. Kinnunen, P.; Emler, R.; Raatikainen, J.; Guignot, S.; Guimerà, J.; Heiskanen, K. Closed water loops, ore sorting and tailings valorization for more sustainable raw material supply. J. Clean. Prod. 2020. under review.

16. Kunz, N.C.; Moran, C.J. The utility of a systems approach for managing strategic water risks at a mine site level. Water Resour. Ind. 2016, 13, 1-6. [CrossRef]

17. Gao, L.; Bryan, B.A.; Liu, J.; Li, W.; Chen, Y.; Liu, R.; Barrett, D. Managing too little and too much water: Robust mine-water management strategies under variable climate and mine conditions. J. Clean. Prod. 2017, 162, 1009-1020. [CrossRef]

18. Ossa-Moreno, J.; McIntyre, N.; Ali, S.; Smart, J.C.R.; Rivera, D.; Lall, U.; Keir, G. The hydro-economics of mining. Ecol. Econom. 2018, 145, 368-379. [CrossRef]

19. Askham, T.M.; Van der Poll, H.M. Water sustainability of selected mining companies in South Africa. Sustainability 2017, 9, 957. [CrossRef]

20. Evdokimova, G.A.; Gershenkop, A.S.; Fokina, N.V. The impact of bacteria of circulating water on apatite-nepheline ore flotation. J. Environ. Sci. Health Part A. 2012, 47, 398-404. [CrossRef] [PubMed]

21. Liu, W.; Moran, C.J.; Vink, S. Managing the potential risks of using bacteria-laden water in mineral processing to protect freshwater. Environ. Sci. Technol. 2013, 47, 6582-6588. [CrossRef] [PubMed]

22. Smith, R.W.; Miettinen, M. Microorganisms in flotation and flocculation: Future technology or laboratory curiosity? Miner. Eng. 2006, 19, 548-553. [CrossRef]

23. Merma, A.G.; Torem, M.L.; Morán, J.J.V.; Monte, M.B.M. On the fundamental aspects of apatite and quartz flotation using a Gram positive strain as a bioreagent. Miner. Eng. 2013, 48, 61-67. [CrossRef]

24. Kim, G.; Park, K.; Choi, J.; Gomez-Flores, A.; Han, Y.; Choi, S.Q.; Kim, H. Bioflotation of malachite using different growth phases of Rhodococcus opacus: Effect of bacterial shape on detachment by shear flow. Int. J. Miner. Proc. 2015, 143, 98-104. [CrossRef]

25. Govender, Y.; Gericke, M. Extracellular polymeric substances (EPS) from bioleaching systems and its application in bioflotation. Miner. Eng. 2011, 24, 1122-1127. [CrossRef]

26. La Vars, S.M.; Newton, K.; Quinton, J.S.; Cheng, P.-Y.; Wei, D.H.; Chan, Y.-L.; Harmer, S.L. Surface chemical characterisation of pyrite exposed to Acidithiobacillus ferrooxidans and associated extracellular polymeric substances. Minerals 2018, 8, 132. [CrossRef]

27. Hirajima, T.; Aiba, Y.; Farahat, M.; Okibe, N.; Sasaki, K.; Tsuruta, T.; Doi, K. Effect of microorganisms on flocculation of quartz. Int. J. Miner. Proc. 2012, 102-103, 107-111. [CrossRef]

28. Ramos-Escobedo, G.T.; Pecina-Treviño, E.T.; Bueno Tokunaga, A.; Concha-Guerrero, S.I.; Ramos-Lico, D.; Guerra-Balderrama, R.; Orrantia-Borunda, E. Bio-collector alternative for the recovery of organic matter in flotation processes. Fuel 2016, 176, 165-172. [CrossRef]

29. Sanwani, E.; Chaerun, S.; Mirahati, R.; Wahyuningsih, T. Bioflotation: Bacteria-mineral interaction for eco-friendly and sustainable mineral processing. Procedia Chem. 2016, 19, 666-672. [CrossRef] 
30. Farahat, M.; Hirajima, T. Hydrophilicity of Ferroplasma acidiphilum and its effect on the depression of pyrite. Miner. Eng. 2012, 36-38, 242-247. [CrossRef]

31. Vasanthakumar, B.; Ravishankar, H.; Subramanian, S. Microbially induced selective flotation of sphalerite from galena using mineral-adapted strains of Bacillus megaterium. Coll. Surf. B Biointerfaces 2013, 112, $279-286$. [CrossRef] [PubMed]

32. Merma, A.G.; Hacha, R.R.; Torem, M.L. Cellular adaptation: Culture conditions of R. opacus and bioflotation of apatite and quartz. REM: Int. Eng. J. 2017, 70, 67-76. [CrossRef]

33. Vilinska, A.; Rao, K.H. Leptosririllum ferrooxidans-sulfide mineral interactions with reference to bioflotation and bioflocculation. T. Nonferr. Metal. Soc. 2008, 18, 1403-1409. [CrossRef]

34. Bleeze, B.; Zhao, J.; Harmer, S.L. Selective attachment of Leptospirillum ferrooxidans for separation of chalcopyrite and pyrite through bio-flotation. Minerals 2018, 8, 86. [CrossRef]

35. Consuegra, G.L.; Kutschke, S.; Rudolph, M.; Pollmann, K. Halophilic bacteria as potential pyrite bio-depressants in Cu-Mo bioflotation. Miner. Eng. 2020, 145, 106062. [CrossRef]

36. Yin, J.; Chen, J.C.; Wu, Q.; Chen, G.Q. Halophiles, coming stars for industrial biotechnology. Biotechnol. Adv. 2015, 33, 1433-1442. [CrossRef]

37. Liu, W.; Moran, C.J.; Vink, S. Impact of chalcopyrite depression by water-borne bacteria in pure and combined mineral systems. Int. J. Miner. Process. 2013, 123, 18-24. [CrossRef]

38. Karthiga devi, K.; Natarajan, K.A. Production and characterization of bioflocculants for mineral processing applications. Int. J. Miner. Proc. 2015, 137, 15-25. [CrossRef]

39. Abu Tawila, Z.M.; Ismail, S.; Dadrasnia, A.; Usman, M.M. Production and characterization of a bioflocculant produced by Bacillus salmalaya 139SI-7 and its applications in wastewater treatment. Molecules 2018, 23, 2689. [CrossRef] [PubMed]

40. Olivera, C.A.C.; Merma, A.G.; Torem, M.L. Evaluation of hematite and quartz flotation kinetics using surfactant produced by Rhodococcus erythropolis as bioreagent. REM-Int. Eng. J. 2019, 72, 655-659. [CrossRef]

41. Diao, M.; Taran, E.; Mahler, S.; Nguyen, A.V. A concise review of nanoscopic aspects of bioleaching bacteria-mineral interactions. Adv. Coll. Interf. Sci. 2014, 212, 45-63. [CrossRef] [PubMed]

42. Chandraprabha, M.N.; Natarajan, K.A. Microbially induced mineral beneficiation. Min. Process. Ext. Metall. Rev. 2010, 31, 1-29. [CrossRef]

43. Koga, Y.; Morii, H. Biosynthesis of ether-type polar lipids in archaea and evolutionary considerations. Microbiol. Mol. Biol. Rev. 2007, 71, 97-120. [CrossRef] [PubMed]

44. Porro, S.; Ramírez, S.; Reche, C.; Curutchet, G.; Alonso-Romanowski, S.; Donati, E. Bacterial attachment: Its role in bioleaching processes. Process Biochem. 1997, 32, 573-578. [CrossRef]

45. Gehrke, T.; Telegdi, J.; Thierry, D.; Sand, W. Importance of extracellular polymeric substances from Thiobacillus ferrooxidans for bioleaching. Appl. Env. Microbiol. 1998, 64, 2743-2747. [CrossRef]

46. Sharma, P.K. Surface Studies Relevant to Microbial Adhesion and Bioflotation of Sulphide Minerals. Ph.D. Thesis, Luleå University of Technology, Luleå, Sweden, 2001. Available online: http://urn.kb.se/resolve?urn= urn:nbn:se:ltu:diva-18301 (accessed on 14 January 2020).

47. Sharma, P.K.; Rao, K.H. Role of a heterotrophic Paenibacillus polymyxa bacteria in the bioflotation of some sulfide minerals. Min. Metall. Expl. 1999, 16, 35-41. [CrossRef]

48. van Loosdrecht, M.C.M.; Lyklema, J.; Norde, W.; Zehnder, A.J.B. Influence of interfaces on microbial activity. Microbiol. Rev. 1990, 54, 75-87. [CrossRef]

49. Olivera, C.A.C.; Merma, A.G.; Puelles, J.G.S.; Torem, M.L. On the fundamentals aspects of hematite bioflotation using a Gram positive strain. Miner. Eng. 2017, 106, 55-63. [CrossRef]

50. Patra, P.; Natarajan, K.A. Role of mineral specific bacterial proteins in selective flocculation and flotation. Int. J. Miner. Process 2008, 88, 53-58. [CrossRef]

51. Florian, B.; Noël, N.; Thyssen, C.; Felschau, I.; Sand, W. Some quantitative data on bacterial attachment to pyrite. Miner. Eng. 2011, 24, 1132-1138. [CrossRef]

52. Sand, W.; Gehrke, T.; Jozsa, P.G.; Schippers, A. (Bio) chemistry of bacterial leaching-direct vs. indirect bioleaching. Hydrometallugry 2001, 59, 159-175. [CrossRef]

53. Kinzler, K.; Gehrke, T.; Telegdi, J.; Sand, W. Bioleaching-A result of interfacial processes caused by extracellular polymeric substances (EPS). Hydrometallugry 2003, 71, 83-88. [CrossRef] 
54. Rohwerder, T.; Gehrke, T.; Kinzler, K.; Sand, W. Bioleaching review part A: Progress in bioleaching: Fundamentals and mechanisms of bacterial metal sulfide oxidation. Appl. Microbiol. Biotech. 2003, 63, 239-248. [CrossRef]

55. Kuyumcu, H.Z.; Bielig, T.; Vilinska, A.; Rao, K.H. Biocoagulation and its application potentials for mineral bioprocessing. Open Miner. Process. J. 2009, 2, 1-11. [CrossRef]

56. Africa, C.-J.; van Hille, R.P.; Sand, W.; Harrison, S.T.L. Investigation and in situ visualisation of interfacial interactions of thermophilic microorganisms with metal-sulphides in a simulated heap environment. Miner. Eng. 2013, 48, 100-107. [CrossRef]

57. Vera, M.; Schippers, A.; Sand, W. Progress in bioleaching: Fundamentals and mechanisms of bacterial metal sulfide oxidation-Part A. Appl. Microbiol. Biotechnol. 2013, 97, 7529-7541. [CrossRef] [PubMed]

58. Yin, S.; Wang, L.; Wu, A.; Kabwe, E.; Chen, X.; Yan, R. Copper recycle from sulfide tailings using combined leaching of ammonia solution and alkaline bacteria. J. Clean. Prod. 2018, 189, 746-753. [CrossRef]

59. San Martín, F.; Kracht, W.; Vargas, T. Biodepression of pyrite using Acidithiobacillus ferrooxidans in seawater. Miner. Eng. 2018, 117, 127-131. [CrossRef]

60. Amini, E.; Hosseini, T.R.; Oliazadeh, M.; Kolahdoozan, M. Application of Acidithiobacillus ferrooxidans in coal flotation. Int. J. Coal Prep. Util. 2009, 29, 279-288. [CrossRef]

61. Schippers, A.; Sand, W. Bacterial leaching of metal sulfides proceeds by two indirect mechanisms via thiosulfate or via polysulfides and sulfur. Appl. Env. Microbiol. 1999, 65, 319-321. [CrossRef]

62. Rawlings, D.E. Heavy metal mining using microbes. Annu. Rev. Microbiol. 2002, 56, 65-91. [CrossRef] [PubMed]

63. Deng, M.; Liu, Q.; Xu, Z. Impact of gypsum supersaturated water on the uptake of copper and xanthate on sphalerite. Miner. Eng. 2013, 49, 165-171. [CrossRef]

64. Kirjavainen, V.; Schreithofer, N.; Heiskanen, K. Effect of calcium and thiosulfate ions on flotation selectivity of nickel-copper ores. Miner. Eng. 2002, 15, 1-5. [CrossRef]

65. Chen, S.; Gong, W.; Mei, G.; Zhou, Q.; Bai, C.; Xu, N. Primary biodegradation of sulfide mineral flotation collectors. Miner. Eng. 2011, 24, 953-955. [CrossRef]

66. Cheng, H.; Lin, H.; Huo, H.; Dong, Y.; Xue, Q.; Cao, L. Continuous removal of ore floatation reagents by an anaerobic-aerobic biological filter. Bioresour. Technol. 2012, 114, 255-261. [CrossRef]

67. Chockalingam, E.; Subramanian, S.; Natarajan, K.A. Studies on biodegradation of organic flotation collectors using Bacillus polymyxa. Hydrometallugry 2003, 71, 249-256. [CrossRef]

68. Dehghan, R.; Dianati, M. The effects of $\mathrm{Pb}-\mathrm{Zn}$ flotation reagents on the bioleaching process by mesophilic bacteria. Int. J. Miner. Proc. 2015, 143, 80-86. [CrossRef]

69. Dopson, M.; Sundkvist, J.-E.; Lindström, E.B. Toxicity of metal extraction and flotation chemicals to Sulfolobus metallicus and chalcopyrite bioleaching. Hydrometallugry 2006, 81, 205-213. [CrossRef]

70. Okibe, N.; Johnson, D.B. Toxicity of flotation reagents to moderately thermophilic bioleaching microorganisms. Biotechnol. Lett. 2002, 24, 2011-2016. [CrossRef]

71. Jafari, M.; Shafaei, S.Z.; Abdollahi, H.; Gharabaghi, M.; Chehreh Chelgani, S.; Ghassa, S. Examining the effects of typical reagents for sulfide flotation on bio-oxidation activity of ferrous iron oxidizing microorganisms. Solid State Phenom. 2017, 262, 84-87. [CrossRef]

72. Bararunyeretse, P.; Yao, J.; Dai, Y.; Bigawa, S.; Guo, Z.; Zhu, M. Toxic effect of two kinds of mineral collectors on soil microbial richness and activity: Analysis by microcalorimetry, microbial count, and enzyme activity assay. Environ. Sci. Pollut. Res. 2017, 24, 1565-1577. [CrossRef] [PubMed]

73. Guo, Z.; Yao, J.; Wang, F.; Yuan, Z.; Bararunyeretse, P.; Zhao, Y. Effect of three typical sulfide mineral flotation collectors on soil microbial activity. Environ. Sci. Pollut. Res. 2016, 23, 7425-7436. [CrossRef] [PubMed]

74. Natarajan, K.A.; Sabari Prakasan, M.R. Biodegradation of sodium isopropyl xanthate by Paenibacillus polymyxa and Pseudomonas putida. Miner. Metall. Proc. 2013, 30, 226-232. [CrossRef]

75. Corbett, M.K.; Eksteen, J.J.; Niu, X.-Z.; Watkin, E.L.J. Syntrophic effect of indigenous and inoculated microorganisms in the leaching of rare earth elements from Western Australian monazite. Res. Microbiol. 2018, 169, 558-568. [CrossRef] [PubMed]

76. Jones, J.G. Freshwater Ecosystems-Structure and Response. Ecotoxicol. Environ. Saf. 2001, 50, 107-113. [CrossRef] [PubMed]

77. Shade, A.; Jones, S.E.; McMahon, K.D. The influence of habitat heterogeneity on freshwater bacterial community composition and dynamics. Environ. Microbiol. 2008, 10, 1057-1067. [CrossRef] 
78. Yannarell, A.C.; Triplett, E.W. Geographic and environmental sources of variation in lake bacterial community composition. Appl. Env. Microbiol. 2005, 71, 227-239. [CrossRef]

79. Bomberg, M.; Mäkinen, J.; Salo, M.; Kinnunen, P. High diversity in iron cycling microbial communities in acidic, iron-rich water of the Pyhäsalmi mine, Finland. Geofluids 2019. [CrossRef]

80. Islam, E.; Sar, P. Culture-dependent and-independent molecular analysis of the bacterial community within uranium ore. J. Basic Microbiol. 2011, 51, 372-384. [CrossRef] [PubMed]

81. Islam, E.; Paul, D.; Sar, P. Microbial diversity in Uranium deposits from Jaduguda and Bagjata Uranium mines, India as revealed by clone library and denaturing gradient gel electrophoresis analyses. Geomicrobiol. J. 2014, 31, 862-874. [CrossRef]

82. Matlakowska, R.; Sklodowska, A. The culturable bacteria isolated from organic-rich black shale potentially useful in biometallurgical procedures. J. Appl. Microbiol. 2009, 107, 858-866. [CrossRef] [PubMed]

83. Adeleke, R.; Cloete, T.E.; Khasa, D.P. Culturable microorganisms associated with Sishen iron ore and their potential roles in biobeneficiation. World J. Microb. Biot. 2012, 28, 1057-1070. [CrossRef] [PubMed]

84. Ghashoghchi, R.A.; Hosseini, M.R.; Ahmadi, A. Effects of microbial cells and their associated extracellular polymeric substances on the bio-flocculation of kaolin and quartz. Appl. Clay Sci. 2017, 138, 81-88. [CrossRef]

85. Morin, K.; Hutt, N. Mine-water leaching of nitrogen species from explosive residues. In Proceedings of the GeoHalifax, the 62nd Canadian Geotechnical Conference and 10th Joint CGS/IAH-CNC Groundwater Conference, Halifax, NS, Canada, 20-24 September 2009; pp. 1549-1553.

86. Forsberg, H.; Åkerlund, H. Kväve och Sprängämnesrester i LKAB:s Malm-, Gråbergs- Och Produktflöden. Master's Thesis, Luleå Tekniska Universitet, Luleå, Sweden, 1999; 116p.

87. Albrecht, T.W.J.; Addai-Mensah, J.; Fornasiero, D. Critical copper concentration in sphalerite flotation: Effect of temperature and collector. Int. J. Miner. Proc. 2016, 146, 15-22. [CrossRef]

88. O'Connor, C.T.; Dunne, R.C.; Botelho de Sousa, A.M.R. The effect of temperature on the flotation of pyrite. J. S. Afr. Inst. Min. Metall 1984, 84, 389-394.

89. Liu, W.; Moran, C.J.; Vink, S. The adverse effect of disrupted water-borne bacteria cells on flotation. Int. J. Miner. Proc. 2016, 157, 128-133. [CrossRef]

90. Muzinda, I.; Schreithofer, N. Water quality effects on flotation: Impacts and control of residual xanthates. Miner. Eng. 2018, 125, 34-41. [CrossRef]

91. Moimane, T.M.; Corin, K.C.; Wiese, J.G. The effect of varying pulp reagent chemistry on the flotation performance of a South African PGM ore. Miner. Eng. 2016, 95, 155-160. [CrossRef]

92. Ikumapayi, F.; Mäkitalo, M.; Johansson, B.; Rao, K.H. Recycling of process water in sulphide flotation: Effect of calcium and sulphate ions on flotation of galena. Miner. Eng. 2012, 39, 77-88. [CrossRef]

93. Ikumapayi, F.K. Recycling Process Water in Complex Sulphide Ore Flotation. Ph.D. Thesis, Luleå University of Technology, Luleå, Sweden, April 2013.

94. Slatter, K.A.; Plint, N.D.; Cole, M.; Dilsook, V.; de Vaux, D.; Palm, N.; Oostendorp, B. Water management in Anglo Platinum Process Operations: Effects of Water Quality on Process Operations. In Proceedings of the Abstracts of the International Mine Water Conference, Pretoria, South Africa, 19-23 October 2009; pp. 46-55.

95. Shengo, L.M.; Gaydardzhiev, S.; Kalenga, N.M. Assessment of water quality effects on flotation of copper-cobalt oxide ore. Miner. Eng. 2014, 65, 145-148. [CrossRef]

96. Lutandula, M.S.; Mwana, K.N. Perturbations from the recycled water chemical components on flotation of oxidized ores of copper-The case of bicarbonate ions. J. Environ. Chem. Eng. 2014, 2, 190-198. [CrossRef]

(C) 2020 by the authors. Licensee MDPI, Basel, Switzerland. This article is an open access article distributed under the terms and conditions of the Creative Commons Attribution (CC BY) license (http://creativecommons.org/licenses/by/4.0/). 